\title{
Michael Longley's Father: Memory, Mourning and History
}

\author{
Barry Sloan \\ University of Southampton, England
}

\begin{abstract}
Copyright (c) 2012 by Barry Sloan. This text may be archived and redistributed both in electronic form and in hard copy, provided that the author and journal are properly cited and no fee is charged for access.
\end{abstract}

\begin{abstract}
Michael Longley's father has been a recurring presence in the poet's work from his earliest to his most recent collection. This paper examines the exceptional strength of that bond reflected in the varied and changing ways in which the poet has responded to it - memorizing and mourning his loss; discovering through his father's First World War stories a means of memorialising loss of life in contemporary conflicts and a way of facing the history of the twentieth century; confronting his own ageing and sense of mortality; and marking the specific, but also representative, generational history of his family. Close readings of key poems are offered to highlight Longley's skills in meeting his own exacting standards of aesthetic propriety and moral and social responsibility for writers of elegy in order to avoid either exploitation of tragedy and loss, or facile gestures of consolation.
\end{abstract}

Key Words. Memory, mourning, history, father, son, elegy, family, consolation.

Resumen. El padre de Michael Longley ha sido una presencia recurrente en la obra del poeta desde el primer volumen al más reciente. El artículo examina la extraordinaria fuerza de este lazo en las diversas y variables maneras en que el poeta lo ha abordado: memorizando y llorando su pérdida; descubriendo a través de las historias de su padre sobre la Primera Guerra Mundial una forma de memoralizar la pérdida de vidas en conflictos contemporáneos y de enfrentarse a la historia del siglo veinte; confrontando su propio envejecimiento y sentido de mortalidad; y celebrando la historia específica, y a la vez representativa, de su familia durante varias generaciones. Se ofrecen lecturas detalladas de poemas clave con el fin de subrayar la habilidad de Longley para alcanzar rigurosos principios de decoro estético y de responsabilidad moral y social que eviten al escritor de elegías caer ya sea en la explotación de la tragedia y la pérdida o los fáciles gestos de consuelo.

Palabras clave. Memoria, luto, historia, padre, hijo, elegía, familia, consolación.

Michael Longley's declaration in 1995 that his "concerns continue to be Eros and Thanatos, the traditional subject-matter of the lyric" (Boran 1995: 147) confirmed that preoccupations long recognised in his work by readers and critics alike were not diminishing in their importance for him. The focus here is principally on a selection of poems presided over by Thanatos. Across his career Longley has established himself as one of the most distinguished writers of elegy in his generation, making repeated returns to it in widely varying contexts and circumstances. Whatever the particular situation, moral scrupulousness, restraint, and meticulous emotional and formal control have characterised the writing of this poet who has insisted on the delicate network of responsibilities within which the elegist necessarily works when addressing the griefs and losses of others. In "Blackthorn and Bonsai," Longley quotes words from nearly twenty years earlier in which he voiced his

ISSN 1699-311X 
impatience with critics who expected artists to provide immediate responses to the "civil discord" of the day, and then elaborates his thinking on this point:

Though the poet's first duty must be to his imagination, he has other obligations - and not just as a citizen. He would be inhuman if he did not respond to tragic events in his own community, and a poor artist if he did not seek to endorse that response imaginatively. But if his imagination fails him, the result will be a dangerous impertinence (1994: 73). ${ }^{1}$

This is why, in his view, patience and time to absorb, weigh and discover - necessarily precede whatever an artist may produce. But in addition to the elegiac poet's moral and imaginative responsibilities, Longley accepts his social role as a guardian of the integrity of language, committed to exploring and testing its potential and limitations as the vehicle to articulate extremities of experience without the indulgence of aestheticizing it, and to offer consolation in the face of irreplaceable loss.

The challenge is complicated by the poet's awareness of how personal experience is embedded within the wider contexts of family relationships and of local, national or international events, which impinge upon the individual, sometimes in the most decisive way. In literary terms, too, the modern elegiac poet belongs in a line of western European predecessors from classical times onwards, and for a practitioner as deeply attuned to that tradition as Longley, this produces another kind of responsibility, although one which may be enabling and enriching rather than merely burdensome.

"Elegies," writes John Lyon, "are at once personal, intimate and immediate, occasioned by a specific loss, and highly literary, enmeshed in a dense intertextuality of poetic forebears" (1996: 242). Poems occasioned by one loss in particular, that of his father, or taking their bearings from it, run like a vertical column down Longley's work from his first collection (1969) to his most recent (2011). By following the course of his enduring poetic relationship with his father long after their separation by death, this discussion explores its

1. These sentences are based closely on words in a letter from Longley to the Irish Times, 18 June 1974, quoted in Brearton (2006: 59) importance in shaping poems in some of the most persistent concerns in Longley's work: history, family and mortality. Unsurprisingly, the relationship has changed over time: the early focus on the poet's sense of loss and on the complex intimacy of his bonds with his father evolved into imaginatively conceived connections between his father's death and other deaths in which Longley himself had no personal involvement; and, more recently, this has altered again as the writer contemplates his own advancing age and new relationships to children and grandchildren. In short, Richard Longley's death was not simply the source of poems where the son commemorates his father and ponders his relationship to him; it is the reference point from which he has mediated and developed his understanding of and his way of writing about death in various contexts over a lifetime. One might also speculate on the extent to which Longley's keenly felt and enduring responsiveness to this "personal, intimate and immediate" bereavement has been a guarantor of the tact and the sense of moral responsibility and obligation which he upholds as priorities in the poetry of human loss; and in a different way that responsiveness equally appears to inform his approach to his own shifting position in the generational hierarchy, and his developing consciousness of ageing and personal mortality.

Richard Longley's life was decisively shaped by his youthful experiences in the 1914-1918 conflict, and his account of those years finally shared not long before his death has exercised a compelling power on his son Michael's imagination. ${ }^{2}$ In Longley's words, "Somehow my father's existence, and his experience, the stories he passed on to me, gave me a kind of taproot into the war" (O'Toole 1985: 17). This is first seen in "In Memoriam” (Longley 1969: 41-2), which establishes personal associations and poetic strategies of lasting importance in Longley's work.

While the title not only recalls Tennyson's famous poem, but also indicates one of the essential purposes of elegy, the opening vocative address to "My father" may echo Dylan Thomas's use of the same phrase in "Do Not Go Gentle Into That Goodnight” where

2. See Tuppenny Stung (1994: 15 and 18). 
another son confronts his father's passing. In Longley's poem, however, perhaps the principal feature is the closeness and complexity of his imaginative engagement with his father's stories, most arrestingly encountered in the projection of his unborn self into the incident when his father-to-be was almost emasculated. "In Memoriam" is a memory poem as well as a memorial poem, and the poet's memory of his father's memories involves a kind of collusion or collaboration with him hinted at in phrases such as "through your eyes/ I read you like a book," "Now I see in close-up, in my mind's eye," and "your voice is locked inside my head." Furthermore, the second sentence in the first stanza, moving from its references to "you" and "your" to the strategically withheld subject, "I," and the main verb, explicitly suggests how father and son have both contributed to the construction of events relayed in the poem as a whole:

\section{Before you died}

Re-enlisting with all the broken soldiers

You bent beneath your rucksack, near collapse,

In anecdote rehearsed and summarised

These words I write in memory.

The notion of death as "re-enlisting" both suggests rejoining other soldiers who fell in battle and anticipates the revelation in the fourth stanza that Longley himself died after "old wounds woke/ As cancer," and that therefore he too was a war casualty. This burden of the past which eventually killed him is reinforced through the reference to Longley "bent beneath" his "rucksack," and in turn calls up familiar photographic images, as well as a phrase from Wilfred Owen's poem, "Dulce et Decorum Est;" and taken in conjunction with the sequence of words "bent," "near collapse," "rehearsed," "summarised" - it points to the effort that has gone into getting the story right and distilling it to its essentials. Through combining intertextual allusions and individual details, Richard Longley's personal wartime "anecdotes" are set within the existing cultural history of the First World War, and simultaneously add to it.

The initial movement from the second to the first person is reversed as the writer imagines his father's horror, ignorance and confusion as a young soldier, and the moment of his shrapnel injury which is both literally and metaphorically at the poem's centre. The significance of this incident turns on its connection with the outcomes which might have resulted from Longley's wounds. The words "your proper funeral urn/ Had mercifully smashed to smithereens" suggest how easily he might have died; and he escaped emasculation even more narrowly, swooning not in ecstasy but with the pain of an injury that seemed to indicate the end of sex before it ever started, and the destruction of the "future" in the sense of children. Contemplating this last possibility, Longley reverts to the first person and imagines his father's wounding as his own "near-death experience" at the same instant. This way of viewing his father's injury and of making it a kind of pre-life history of his own proposes an exceptional bond between the two men, the full significance of which has subsequently become apparent. The punning wittiness of the idea that Michael Longley "In No-Man's Land was surely left for dead" aptly connects the First World War battlefield on which his father was injured with the non-place in which his unconceived "son" was somehow awaiting his conception twenty odd years later, and forty years before "In Memoriam" was written. And just as the poet was "locked" in his father's sperm when he was wounded, so now the voice of the dead man is "locked" in his son's head.

That voice is released in the fourth stanza where in a reversal of the father-son hierarchy, the older man confesses to the younger his post-war sexual adventuring undertaken to prove the survival of his manhood. We read that this confession was "the last confidence" the father reposed in his son, and in what Fran Brearton calls "an extraordinary gesture of imaginative compensation” (2006: 39), the final stanza contains the poet's unequivocally humane and compassionate response to it. This is not only a kind of last rite for the dying man as his son "summon[s]" back the girls from his father's youth to accompany him "Underground," but enables the poet to implicate himself non-judgementally in his father's disclosures as "those lost wives as recreated brides/ Take shape before me, materialise.” The final image of these imagined women "lift[ing] their skirts like blinds" across 
his father's eyes simultaneously evokes the sexual teasing of chorus girls and the notion of the dying man's sight fading, and may either suggest that he passes into a pleasureable darkness, or that whatever lies beyond death, if anything, is concealed as if by a blindfold. The line also echoes the close of Owen's "Anthem for Doomed Youth" but shifts the emphasis from the grief of bereaved families who draw down the blinds in their homes as a mark of respect, to the dying man himself. Thus, one last time, "In Memoriam" moves between perspectives - between past and present, and between private intimacy and emotion and intertextual allusion and broader, public frameworks of reference. This dynamic sustains the poem's equipoise and density of feeling throughout, and is inseparable from its humane and consoling treatment of death and loss.

Longley's entirely imaginative identification with the battlescapes of the First World War through his father's stories was soon increasingly complicated by his experience of the violence in Northern Ireland in the 1970s and 1980s. In "Wounds” (Longley 1973: 40-1), the very structure of the poem reflects this situation: the first stanza takes up again the close bonds between son and father seen in "In Memoriam" and focuses on "two pictures from my father's head" related to the war; the second refers to contemporary killings in the "troubles," providing three more "pictures" which suggest both continuity with the past, and that violent death may be anyone's fate, soldier, child or civilian. Furthermore, it may occur in a nursery or a living room, and may be delivered by "a shivering boy" just as easily as by a member of the armed forces. For teenage British soldiers of the 1970s Northern Ireland has replaced France of the First World War as the foreign land in which they perish, but the child and the bus conductor commemorated in the poem are killed in their own homes by fellow countrymen. The chaos may not be on the scale of the Somme, but the appalling suffering and human consequences are comparable. Thus Richard Longley's bewilderment in July 1916 is recalled in the "bewildered" wife whose husband has been slain beside her, and the boy killer's supposed apology links him with other equally youthful and similarly confused soldiers, whether at the Somme or naively heading out for a night on the town in Belfast.

Through linking examples of the destructiveness of war from two separate generations and situations to suggest how they are variants on a universal human theme, "Wounds" marks an advance in Longley's elegiac writing. The metaphor of the poet "burying" victims of the Northern Irish conflict "beside" his father, the "belated casualty" of the Great War, enables Longley to avoid what he called the "deadly danger of regarding the agony of others as raw material for your art, or your art as solace for them in their suffering" (Healy 1995: 560). Rather than merely juxtaposing personal loss with other losses known only by report, the image of a common burial for these - and, by inference, all victims of conflict - overcomes such distinctions and makes it a democratically inclusive elegy. The implications of the poem's title are equally farreaching, alluding not only to the physical "wounds" of war and sectarian strife, but to lingering psychological injuries, whether those carried for decades by the poet's father, or embedded in Northern Irish history, and motivating the latest cycle of suffering.

In the way it refrains from offering consolation, "Wounds" exemplifies one of the dilemmas facing modern elegists: on the one hand the kind of "wounds" and losses addressed in the poem elude any form of verbal compensation, and on the other, there is no suggestion of comfort to be drawn from faith, or from some larger framework of understanding which might make war and its human costs comprehensible. What the poem offers - perhaps all it can offer - are the harmonies of the formal control with which it is written and which constitute a ceremony with Yeatsian echoes that complements the imagined secular burial and act of remembrance conducted by the poet. The importance of this should not be underestimated because such an act of memorialisation, which affirms and preserves the dignity of the individual, acquires particular urgency in an age of mass killing, sectarian atrocities and anonymised death. However, there is no confusion between the poem's recognition of grief and loss and its simultaneous awareness of its own limitations as an agent of consolation. The selfknowingness implied here is inseparable from the poet's tact towards his subject matter and 
avoids any temptation to exploit it for a sensational or facile emotive effect based on the presumptuous misappropriation of others' grief which he so deplores.

Longley was to re-employ the notion of reburying his father with victims of the "troubles" in "The Linen Workers," the last of the three poems in "Wreaths" (1979: 12-3). In the final stanza, which prepares for, but does not actually represent this event, the poet again insists on the need first of all to restore dignity to his dead parent by replacing the material objects of daily life which he has been divested of in death. By implication, the poem also gives back dignity in the same way to the shattered bodies of the murdered linen workers and to other victims of violent death, such as the civil servant and greengrocer to whom the first two "wreaths" are dedicated, through this symbolic act of re-ordering. Thus, while Longley's father may no longer be the focal point of this elegy, he has become the indispensable figure whose memory must first be re-summoned before the poet can approach the other dead men.

"Wreaths" was published in The Echo Gate (1979), Longley's last full collection until Gorse Fires (1991), although Poems 19631983 (1985) included fifteen "New Poems." One of these, "The Third Light" (Longley 1985: 200), memorialises the poet's mother, Constance, who had died in 1979. Longley has recorded how in the last year or so of her life, when they both knew of her impending death, they spent time together daily. "Over several tumultuous months," he writes, "we lived out her childhood and mine;" and this included revelations of his mother's unhappiness as a child and her confession of an "amateurish" attempt to abort her twin sons "in the early days of her pregnancy. ... Somehow this knowledge made it easier for me to hug her dying lopsided body. It was like a courtship, and I accompanied her on my arm to death's door" (Longley 1994: 29). This image is present in "The Third Light" where, in Brearton's words, "his mother's grave is a marriage bed and her interment an act of love" (2006: 158). Longley represents his own role in this ritual ambiguously: he is at once groom to his mother, kneeling to marry her, and a paternal figure "hand[ing] her over" to her late husband in death in a scene full of material details that would be at home in a painting by Stanley Spencer.

The title's allusion to the superstitious distrust of accepting "the third light" from a match associated with First World War soldiers and shared by Longley's mother, anticipates the poem's interrogative conclusion which includes references linking it to the earlier elegies for his father:

Waiting to scramble hand in hand with him

Out of the shell hole, did you imagine

A Woodbine passing to and fro, a face

That stabilises like a smoke ring?

The question ponders the relationship between the scarred and decorated war veteran and the woman ten years his junior, disabled by "a congenital hip malformation" who had had a childhood of "daily humiliations, mental and physical cruelty" at the hands of an "insanely jealous" (Longley 1994: 19) stepmother, but it discreetly resists presumptuous claims or knowledge.

Later, the poem of dedication in Gorse Fires, "In Memory of My Parents" (Longley 1991: np), revisits the site of this grave. Its four lines evoking a sense of tender intimacy and homely union within the natural world might be read as a realisation of the resolved marital relationship imagined in "The Third Light:"

Between now and one week ago when the snow fell, a bird landed

Where they lie, and made cosier and whiter the white patchwork:

And where I imagine her ashes settling on to his collarbone,

The tracks vanish between wing-tips symmetrically printed.

This poem's brevity and concentration, its high dependence on precise literal and imagined detail, and its containment within one sentence announce features of style which, although not unprecedented in Longley's work, assume a new prominence from Gorse Fires onwards. "In Memory of My Parents" moves elegy beyond the drama of the moment of death or the aftermath of bereavement in which the poet felt complex involvement, to a point of quiet reflection after the disruption of death has been assimilated and when, perhaps, it seems, as Whitman put it, that "to die is different from what any one supposed, and luckier" (1964: 29). 
"Laertes" (Longley 1991: 33) the most significant son-father poem in Gorse Fires, confirms a wholly new approach to the relationship. One of seven poems in the collection which draw upon Homer's Odyssey, the relevant passage in this case, from Book xxiv, concerns the reunion of the hero with his father, Laertes, on the return of the former to Ithaca. Insofar as the poem offers an oblique view of Longley's relationship with his own father it expands on the perspective originally seen in "In Memoriam" where the poet is the stronger figure and the father is frail and shrunken, more an elderly employee retained as a gardener because of long service than a noble figure from the Odyssey. Idiomatic phrases - "gardening duds," "a goatskin duncher," "blurt out" - further domesticate the poem and introduce Irish colloquialisms into the original context and effect "the transition from Greek epic to contemporary lyric, in which process the poem is transformed into a lament for the poet's own father" (Brearton 2006: 171).

The poem is one majestically controlled periodic sentence which navigates its way from Odysseus' first sighting of his father to their eventual emotionally charged embrace. It revolves around the men's mutual recognition because although Odysseus identifies his father at the outset, it is not "Until Laertes recognised his son" that there is a cathartic release of emotions. The suspense and drama involved may be highlighted by following the verbal phrases that initially build up to the pivotal ninth line, the midpoint of the poem. These then enter a second movement from lines ten to fourteen which centre on Odysseus, summoning memories of "a childhood spent traipsing after his father," before entering the final four line movement which begins with Laertes' moment of recognition and seizing of his son, and is completed by Odysseus protectively embracing his father. These movements may be mapped as follows:

Line 1 When he found Laertes First Movement ...

Line 6 Odysseus sobbed

Line $7 \quad$... all he wanted

Line 8 Was to kiss him ... hug him... blurt out

Line 9 But the whole story is one catalogue and then another

Second Movement

Line 10 So he waited
Line 15 Until Laertes recognised his son and ...

Third Movement

Line 16 ... flung his arms [around the neck of great Odysseus]

Line 17 Who drew the old man ... held him there

Line 18 And cradled ... [his dwindling father].

As this shows, Longley here revives his preoccupation with the effects of time and ageing on the son-father relationship. The returning son has to recognise his father in the much changed figure he sees, and it seems characteristic of this poet's temperament that he does not represent Odysseus rushing to meet Laertes. Rather, he pauses first to allow himself time to reconstruct the memory of the past in this same garden when his father had the strength and fitness he himself now possesses and when, conversely, he had only the weakness of a child. Now it is his father who is weak, but with the weakness of age. ${ }^{3}$ This reflective interval prepares us for the final images of Laertes flinging himself, childlike, on his son and of Odysseus supporting "like driftwood the bones of his dwindling father." Linguistically the simile encapsulates the shrunken, bleached, angular brittleness of Laertes' body from which all flesh seems to have departed, although the participle suggests that he is continuing to fade towards a vanishing point. Emotionally the lines are an extraordinary evocation of the paradox whereby, while an adult forever remains the child of his parents, he may come to assume a unique form of surrogate parental responsibility for them. Furthermore, Longley's imaginative possession and rewriting of the classical source suggests the timelessness of this recognition.

In The Weather in Japan (2000), Snow Water (2004) and A Hundred Doors (2011) Longley makes further, but briefer, returns to his father. While it is the case that Richard Longley continues to be an enabling figure in the poet's approaches to personal loss and historical trauma, in these three collections he is now linked on occasion with Edward Thomas. ${ }^{4}$ Thus, in "The Moustache” (2000: 24)

3. There is a similarity of perspective here with Seamus Heaney's “Follower” (1966: 24-5) which also focuses on the reversed roles of father and son as a result of ageing.

4. Thomas had already featured in "Edward Thomas's 
Edward Thomas, Richard Longley and Michael Longley are brought into relationship with each other through the grammar of the poem's single sentence as much as by the juxtapositions it creates:

The moustache Edward Thomas grew to cover up His aesthete's features, the short-back-and-sides hair-do That moved him to the centre of modern times, recall My father, aged twenty, in command of a company Who, because most of them shaved only once a week And some not at all, were known as Longley's Babies.

Through thinking of the moustache common to the two First World War soldiers, worn to make them look more manly, and their shared hairstyle, the poet who literally is Longley's baby (unlike the boy recruits) imaginatively conjoins his biological parent with a literary "father." 5 Thomas is a poet with whom Longley shares a minutely observant passion for the natural world and a keen sense of mortality, but the description of him being "moved to the centre of modern times" by the war also testifies to the writer's abiding belief in the importance of that experience in prefiguring much of the history of the twentieth century: just as his actual father enabled him to approach the war culture of the period, so Thomas is an exemplary literary figure of the age. ${ }^{6}$

War Diary" and "Mole" (Longley 1976: 38 and 39). He has since appeared in "Poetry" and "The War Graves" (Longley 2000: 21 and 22-3); "Edward Thomas's Poem" (Longley 2004: 35); "A Gust," "Footnote" and "Vimy Ridge" (Longley 2011: 33, 34, and 39. Alan J Peacock calls Thomas "a talismanic presence" (Peacock and Devine 2000: 144-45) in The Weather in Japan and suggests that the conflation of Thomas's image with that of Longley is as significant as the twinning of Laertes with Longley in the earlier poem.

5. A further link between the two men may also be hinted at in the reference to "the short-back-andsides hair-do" since this was still a common style for boys during Longley's own youth.

6. 'The Choughs' (Longley 2000: 25) is another example of how memory of his father's wartime stories has prompted the poet to write. Like "The Moustache" it relies on a series of imaginative associations. In this case, observing the "red claws" of the choughs in flight Longley recalls his father's account of "how the raw recruits would clutch/ Their 'courting tackle' under fire," which leads to
In “January 12, 1996” (2000: 25) Longley marks the centenary of his father's birth in four lines of deceptive simplicity which seem to begin with the informality of a conversational remark:

He would have been a hundred today, my father, So I write to him in the trenches and describe How he lifts with tongs from the brazier an ember And in its glow reads my words and sets them aside. $^{7}$

However, held in suspense until the end of the first line, the phrase "my father" not only occupies a key place in the grammar of the sentence and the structure of the poem, but also sits appropriately close to the poet's reference to himself in the next line. In this way "my father" and "I" are brought together for the symbolic exchange imagined in the rest of the poem.

The poet locates his father not where he ever saw or knew him, but in the situation he identifies with him more powerfully than anywhere else - the trenches; and he casts himself as a writer, which he had yet to become at the time of his father's death. Time collapses into an eternal present across which the man in the trench long before he became a father can read the words written by his son long after his passing. The closing phrase is particularly enigmatic. Does it imply the father's acceptance or rejection of the words, or, perhaps most likely, does it resist any such reading and remain open, declining the self-

the notion that "Choughs at play are the souls of young soldiers/ Lifting their testicles into the sky." This elegy is not for his father but for the many young men who died in World War 1; however, its focus on the instinctive but futile attempts of the recruits to protect their genitals from injury inevitably reminds an informed reader of the trauma of Major Longley's own narrow avoidance of emasculation, and of the early poem, "In Memoriam.” Here the poet's personal engagement is less complex and immediate, but as in "In Memoriam" and "Wounds" it is the recollection of his father's words that provides the necessary third term between the descriptive opening and the metaphorical conclusion to the poem.

7. Although perhaps only a coincidence, it is interesting that the first collection of poems by Robert Graves, a writer much admired by Longley, was published in 1916 when he was on active war service, and had the title Over the Brazier. 
indulgence of a less ambiguous closure? It is pertinent here to recall a comment of $\mathrm{W}$ David Shaw. Writing of Tennyson's "striking indeterminacy" in In Memoriam, he cautions against "the real temptation in reading elegies ... to make them less tremulous and hovering than they are" (Shaw 1994: 6). It is a temptation we should not fall into in reading "January 12, 1996” which exemplifies precisely the kind of elegiac reticence and resistance to closure identified by Shaw.

As that poem prefigures, Longley has continued to explore further ways of bridging the ever-increasing time between his father's life and his own. So, for example, having represented his father picking out a melody on a harmonica dropped by "A tommy" in the symbolically apt "No Man's Land” (Longley 2004: 39) he likens him to Anaximines, the ancient Greek philosopher. "Harmonica" continues:

Our souls are air. They hold us together. Listen.

A music-hall favourite lasts until the end of time.

My dad is playing it. His breath contains the world.

The wind is playing an orchestra of harmonicas.

If, as Anaximines suggested, air is the original "material" of the universe from which everything derives, then it is in air that we are most closely united, whether living or dead. Furthermore, the harmonica music is produced by blowing air, and the harmonica is an instrument closely associated with many of the enduring melodies (airs) from the First World War. Therefore in a sense we "hear" the air which is our common source when we hear a harmonica played, and in that way Longley's father's "breath contains the world"; but the association also works in reverse, because the sound of the wind blowing itself calls to mind the tunes played on the harmonica.

“The Front” (Longley 2004: 40) is even more complex in its implications, not simply revisiting the idea of the reversed roles of father and son, but adding to it. Whereas previously Longley projected his dying father as haunted by war memories which he finally imparted to his son, the poet, now almost exactly his father's age when he died, represents himself here as filled with his own dreams of war:

I dreamed I was marching up to the Front to die. There were thousands of us who were going to die.

From the opposite direction, out of step, breathless,
The dead and the wounded came, all younger than my son,

Among them my father who might have been my son.

'What's it like?' I shouted after the family face.

'It’s cushy, mate! Cushy!' my father-son replied.

This is perhaps Longley's "Strange Meeting," and it is as disconcerting in its own way as Owen's poem, an effect reinforced by the disruptions caused by the short sentences and end-stopped lines. He himself is now the mid-generational figure, on his way to die, and passing the ghosts of the already dead reminds him of his own son (and, by implication, of his eventual death, too) as well as confronting him with the specific image of his father. In the same way as the poem replaces measured time and history with a sense of continuum, so it also conflates the roles of fathers and sons across the generations, merging them in the closest possible way and ultimately rendering them indistinguishable. The "father-son's" reply to the speaker's question strikes a note of ironic cheeriness that seems entirely right in the context, and offers the only kind of uneasy comfort available to the still living.

This conflation of the generations continues in A Hundred Doors where one poem declares: "We are both old soldiers, now, my father and I" (Longley 2011: 38); but once again the poet has found a new perspective on some of the specific details of his father's war service from his recently acquired copy of "The citation for my father's Military Cross.” Realising that this testimony to his father's "Conspicuous gallantry and devotion to duty" was written in prose that formed rough decasyllabic lines, Longley has merged the official record of his father's heroic conduct with his own latest tribute of filial love and admiration. ${ }^{8}$ This is fulfilled in the concluding sentence - "Kept alive by his war and momentum,/ I shiver behind him on the fire-step" - which reflects how, irrespective of his own achievements, "citations" and awards, the son still regards himself like a young recruit, dependent on the inspirational and enabling example of his father which has never ceased to fortify his creative imagination and, as it were, summon him to action as a writer.

8. In a review of A Hundred Doors, Kate Kellaway (2011) refers to Longley's comments on this and to his speculation that the writer may have had a classical education. 
"Citation" and "Old Soldiers" are among a small group of works in A Hundred Doors which evoke the landscape of the First World War, but one of its most distinctive features is a sequence of celebratory poems for the writer's six grandchildren near the beginning of the collection, while a further poem for his youngest grandchild placed almost at the end marks an expansion of the kind of crossgenerational family history explored in "The Front.” “A Mobile for Maisie” (2011: 47) exhibits several signature features of the style Longley has perfected over the years. Dense with implication despite its brevity, thirteen of its fourteen lines form one modulated periodic sentence which delays the introduction of the subject and main verb until lines four and eight respectively, and where the grammatical control reinforces connections set up through significantly juxtaposed details and strategically placed parentheses. The poem opens with another characteristic device - a list of apparently random items (“... old parcelstring, a spool, safety/ Pins, cotton wool, clothes pegs, tartan scraps...") which we subsequently discover have been used by Maisie's mother, who is Longley's daughter and an artist herself, to improvise a mobile. We also realise that this creative process is now being mimetically complemented in the making of the poem; but in addition, Longley also improvises his grand-daughter's ancestry. The "tartan scraps" are explained by the poem's first parenthesis - "(Your father sews kilts in the next room)" - , which immediately precedes the introduction of "Your mother who has painted the shutters ...", and at the same time prepares for the second parenthesis, nine lines later - "(Your great-grandfather, my father, wore/ A kilt in the Great War)... ." Thus four generations are woven together in a single sentence.

By using the metaphor of a "Matter-of-fact rosary" for the mobile, Longley not only alludes to its ordered physical structure, but to the way his poem is a non-religious appropriation of the Catholic pattern of prayer which he adopts to commemorate significant family history and the succession of the generations. The second metaphor likening the mobile to the famous rope bridge in Co. Antrim invokes its suspended shape; but it also becomes an image of the generational bridge that extends equally back in time from the new-born child to her ancestors, and forward from them to her. This dual idea is caught in the extraordinary separation of the introductory part of the phrase - "a Carrick-a-Rede bridge that stretches far back" - from its closing words - "and home again" - by the poem's second parenthesis. As a result, when the poem is heard, it is impossible to know whether these last words refer to the bridge leading in either direction, or to the child's greatgrandfather returning from the Great War.

The focus, however, remains on Maisie throughout with six reiterations of the word "your," as well as the double usage of "you" in the two short sentences of the final line, which affirm the maternal nurture and protection that enfold the child, and the intimate bond between mother and daughter. Longley's memory of his father may not be the motivating force behind the poem, but his presence in it is the latest demonstration that he remains an unforgettable point of reference for the poet himself, outlasting the effects of time and change; and that Longley's desire now as an ageing man and a grandfather who is ready to contemplate his own final resting place at Carrigskeewaun (mentioned in "The New Window" and "Greenshank" (2011: 3 and 48)), is to uphold his father's place in the family lineage and pass his memory on to another generation.

This discussion demonstrates, therefore, that it would be difficult to overstate the importance of this son-father relationship and of Longley's endless pondering over it in shaping and informing his vision of the human situation in his own lifetime and across the twentieth century. The early realisation of how easily he might never have been born - and, by implication, of the unknowable numbers of other "children" who were never born because of the injury or death of their potential fathers - has exercised a compelling power on Longley, creating a highly unusual strength of association with his father and linking him in his imagination with his father's war stories. It is perhaps not altogether surprising, therefore, that, as we saw in "The Front" and "Old Soldiers", Longley has finally arrived at the point of conceiving of himself as a fellow combatant alongside his own (dead) father.

The Great War has long assumed almost mythological status in popular thought as a watershed in European history, inaugurating the militarism and sufferings of the modern 
world, and separating it from the pre-war period in the way memorably suggested by Philip Larkin's “MCMXIV.” For Longley, the emphasis is not on the world before the First World War, but on the one shaped by it, and his own father has been an iconic figure for him in this history and its consequences through whom he has repeatedly mediated his view of the world and of life's transience. As a result, he has not only commemorated his father and his relationship with him, much of it constructed retrospectively after his father's death, but has found it natural and coherent to do so in language that has been described as "constitut[ing] in itself a moral way of being in the world” (Grennan 1999: 274), and from a perspective on life as a whole that is essentially elegiac.

\section{Works Cited}

Boran, Pat. 1995. “The Future is Behind Us”. (Interview) Books Ireland 187. 147-8.

Brearton, Fran. 2000. The Great War in Irish Poetry. Oxford: OUP. . 2006. Reading Michael Longley. Tarset, Northumberland: Bloodaxe Books.

Grennan, Eamon. 1999. Facing the Music. Omaha, Nebraska: Creighton University Press.

Healy, Dermot. 1995. “An Interview with Michael Longley”. Southern Review 31, no. 3. 557-61.

Kellaway, Kate. 2011. “A Hundred Doors by Michael Longley - review”. The Observer. 20 March http://www.guardian.co.uk/books/2011/mar/20/a-hundred-doors-michael-longleyreview?INTCMP=SRCH [Retrieved 14/4/2011]

Longley, Michael. 1969. No Continuing City. Dublin: Gill and Macmillan. . 1973. An Exploded View. London: Victor Gollancz. 1976. Man Lying on a Wall. London: Victor Gollancz. 1979. The Echo Gate. London: Secker and Warburg. . 1986. Poems 1963-1983. Harmondsworth: Penguin Books. . 1991. Gorse Fires. London: Secker and Warburg. 1994. Tuppenny Stung. Belfast: Lagan Press. . 2000. The Weather in Japan. London: Jonathan Cape. . 2004. Snow Water. London: Jonathan Cape. . 2011. A Hundred Doors. London: Jonathan Cape.

Lyon, John. 1996. “Michael Longley’s Lists”. English 45, no. 183. 228-46.

O’Toole, Fintan. 1985. “Making Some Kind of Sense”. (Interview) Sunday Tribune. 17 March, 17.

Peacock, Alan J and Devine, Kathleen (eds). 2000. The Poetry of Michael Longley. Gerrards Cross: Colin Smythe.

Shaw, W David. 1994. Elegy and Paradox: Testing the Conventions. Baltimore: Johns Hopkins University Press. Whitman, Walt. 1964 (1947). Leaves of Grass. London: Dent.

Received 13 June 2011 Last version 21 $1^{\text {st }}$ September 2011

Barry Sloan is a Senior Lecturer in English at the University of Southampton (UK). He is the author of The Pioneers of Anglo-Irish Fiction 1800-1850 (1986) and Writers and Protestantism in the North of Ireland (2000). Recent publications include: "The Remains of Protestantism in Maurice Leitch's Fiction” in Elmer Kennedy-Andrews (ed.), Irish Fiction Since the 1960s (2006); “"Drawing the Line and Making the Tot': Aspects of Irish Protestant Life Writing” in Liam Harte (ed.), Modern Irish Autobiography: Self, Nation and Society (2007); “'In My Father's House’: Renegotiations of Boyhood in Life Writing by John McGahern, Ciaran O'Driscoll, Dermot Healy and Ciaran Carson” (2009); “"Each Neighbourly Murder": Lost Lives and the challenge of commemorating the victims of the Northern Ireland troubles”" (2010); "When Parents Die: John Montague and Paul Durcan’s Poetics of Loss and Recovery” (2011). 